\title{
The walrus, Odobenus rosmarus (L.), as a "Danish" faunal element during the Weichsel Ice Age
}

\author{
ULRIK MøHL
}

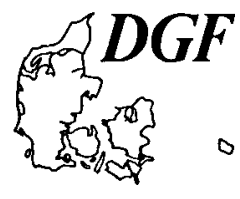

\begin{abstract}
Møhl, U.: The walrus, Odobenus rosmarus (L.), as a "Danish" faunal element during the Weichsel Ice Age. Bull. geol. Soc. Denmark, vol. 34, pp. 83-85. Copenhagen, December, 19th, 1985. https://doi.org/10.37570/bgsd-1985-34-08

Two recent datings of walrus skull fragments from the North Sea, giving the C-14 ages $24380 \pm 620$ years before 1950 and $30880 \pm{ }_{1110}^{1270}$ before 1950 respectively, show that as a faunal element the walrus can be traced back to the time before the main thrust of the Weichsel Ice Age.
\end{abstract}

Ulrik Møhl, Zoological Museum, Universitetsparken 15, DK-2100, Denmark. July 17th, 1984.

\section{Introduction}

Finds of subfossil parts of walrus from Denmark have frequently been described during the past 100 years and their location in time discussed especially in the geological literature (Johnstrup and Steenstrup 1882, Jessen 1899, Nordmann 1905, 1944, Møhl 1974, 1975). Essentially it deals only with the many finds of tusks appearing now and then on the west coast of Northern Jutland off Rubjerg Knude, locally known as "Tvornet".

During the years it became more and more universally accepted to regard these finds from Rubjerg Knude as belonging to an early stage of the late glacial age (Younger Yoldia Clay) or even older. This view harmonized with other finds from Northern Jutland where an arctically influenced marine fauna was represented by mollusc shells as well as bones.

In 1974 one of these tusks, representing an entire find, was C-14 dated (K 1934). The age was $460 \pm 100$ years before 1950 . Thus the tusks moved from the late glacial age up into historical time. Another dating (K 2029) of a part of a mandible from Salling gave an age of $3930 \pm 100$ years before 1950 corresponding to the last part of the Neolithic.

\section{New datings}

The few datings mentioned above are important but further data were required to perceive more about the natural occurrence of the walrus at the coasts of Denmark or adjoining seas. Consequently two additional datings were performed on cranial fragments fished up from the sea bottom off Esbjerg. Cranial fragment no. 10 (numbers given are the accession numbers of the Zoological Museum issued chronologicall as the finds arrived) was submitted to the Zoological Museum in 1911 with no further bearings than "fished up in the North Sea off Esbjerg" and may thus very well come from seining at the Dogger Bank. This skull fragments consist of the snout region with the tusk and the four molars of the right side still in place while the left side of the upper jaw with the tusk and molars is virtually worn away, only the remnants of the alveoli of the three anterior molars being traceable, though the root of the foremost molar can still be seen in situ (Fig. 1). The unilateral wear of the right side of the skull might indicate that it has been lying firmly fixed in the sea bottom sediment with the right side up and then gradually has been exposed to the wearing agents. The fragment is rather damaged and corroded from its stay at the bottom of the sea and according to its size, i.e. the narrow snout region and the slender tusk, it derived from a walrus cow, and adult female ( $q$ ).

The dating (K 3727) resulted in an age for this walrus of $24380 \pm 620$ years before 1950 or 22430 B.C. in C-14 years.

The second find, no. 11 was submitted in 1938 by fisherman J. P. Jensen, Esbjerg, explaining in a letter of the 1st September that the skull has 
been fished up 40 nautical miles NW of Lyngvig lighthouse in 18 fathoms of water. This find too consists of the anterior part of the skull, however both tusks are missing whereas the molar rows are intact with four molars sitting in place in each half of the jaw (Fig. 2). Judging from the large alveoli of the tusks and the consequent considerable breadth across the snout this fragment comes from a walrus bull $\left(\sigma^{\prime}\right)$.

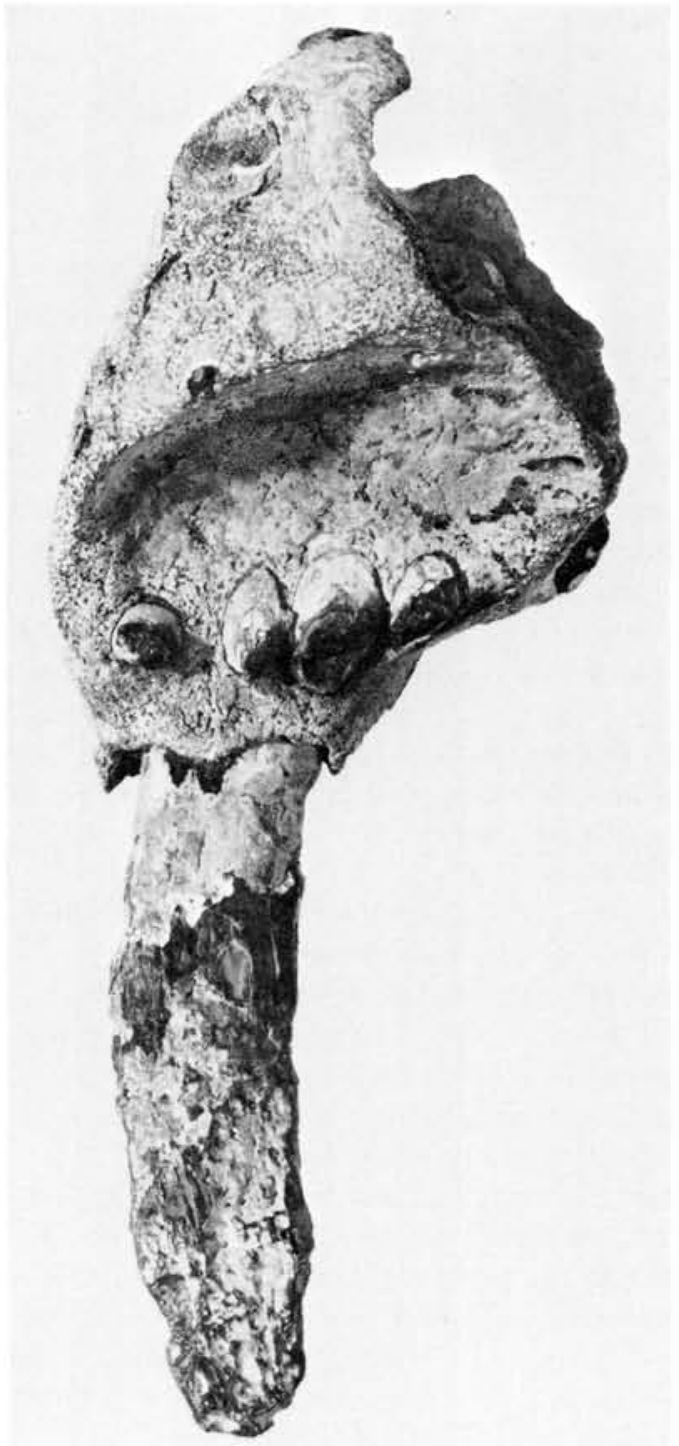

Fig. 1. Find no. 10. Walrus 9 , anterior part of the skull with the corroded tusk as well as the four molars of the right side in situ (viewed obliquely towards the palate).

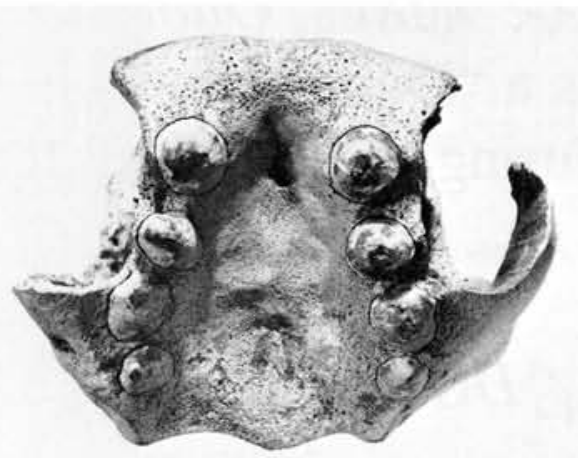

Fig. 2. Find no. 11. Walrus $\sigma^{\prime}$, snout region with molars sitting in place flanked by the alveoli of the disappeared tusks (viewed towards the palate).

The dating ( $\mathrm{K}$ 3726) gave an age of $30880 \pm{ }_{1110}^{1270}$ years before 1950 or 28930 B.C. in C-14 years.

The datings were surprising, indeed almost straining to the mind. However, we cannot know whether these skull fragments have been fished up from primary bed or whether the currents have possibly moved them shorter or longer distances. Forthermore we are not aware of neither the position then of the edge of the fast ice nor the extension of the sea ice where the walrusses breed and find their food. In addition we are ignorant of the composition of the contemporary fauna, finds of which are almost non-existing as far as the mammals are concerned. A presumed contemporary terrestrial fauna is suggested by the many finds of teeth and bones from mammoths in Norway, Sweden and Denmark, where recent datings indtroduce the mammoth in these Northern countries in a time interval ranging in round figures between 45000 and 13000 years before 1950 as regards Norway and Sweden (Berglund 1976). The Danish dated mammoth finds are situated in this period too (Selsing 1982, Aaris-Sørensen and Strand Petersen in prep.).

Thus through these datings of walrus as well as of mammoth we obtain a certain knowledge of the marine and terrestrial fauna before the main thrust of the Weichsel ice reached the country.

A third find of walrus (also a skull) fished up from the North Sea near Brown Bank has been described in the Netherlands (Erdbrink 1972) and is presumed to date from a Weichsel interstadial or possibly an Eem interglacial. 
It is common to these finds (the three skull fragments from the North Sea and the mandible from Salling) representing the fauna that they are skeletal fragments and not just loose tusks which are often only examples of historical articles of commerce like the seven from Rubjerg Knude.

Although these scattered finds and their datings yield only sporadic information about the occurrence of the walrus one obtains however a closer contact with this spectacular, large arctic animal by the positive knowledge of its natural occurrence in the sea around the coasts of Denmark of that age.

The subfossil finds representing only a very small fraction of a primary population these three finds indicate that during the advance of the Weichsel ice we have had a larger population of walrusses in the drift ice covered sea north and west of the present Denmark.

In our minds we must visualize an arctically influenced fauna where the mammoths together with the accompanying elements of the fauna have roamed the land while the sea with its drift ice has created feeding conditions suitable for the walrusses and other marine mammals belonging to the arctic fauna sphere and the closely linked food chain.

Acknowledgements. The Danish text was kindly translated by Mr. L. Serritslev.

\section{Dansk Sammendrag}

To nyere dateringer af fragmenter af hvalroskranier fra Vesterhavet giver aldre på $24380 \pm 620$ og $30880 \pm{ }_{1210}^{1270}$ før 1950 . Dette betyder at hvalrossen som faunaelement kan spores tilbage til tiden før Weichel hovedfremstødet.

\section{References}

Berglund, B. E., Håkansson, S. og Lagerlund, E. 1976: Radiocarbon-dated mammoth (Mammuthus primigenius Blumenbach) finds in South Sweden. Boreas 5, 177-191. Oslo.

Erdbrink, D. P. 1972: Two late pleistocene pinnipede remains in a private collection. Lutra, vol. 14. Leiden.

Jessen, A. 1899: Geologisk Kort over Danmark. Kortblade Skagen, Frederikshavn, Hjørring og Løkken. Danmarks geol. Unders., rakke 1, 3. København.

Johnstrup, F. 1882: Om de geologiske Forhold $i$ den nordlige Del af Vendsyssel. Indbydelsesskrift til Universitetets Aarsfest til Erindring om Kirkens Reformation. København.

Møhl, U. 1974: Subfossil finds of walrus from Denmark. Bull. geol. Soc. Denmark 23, 303-310. Copenhagen.

Møhl, U. 1975: Hvalrosfundene ved Rubjerg Knude. Vendsyssels Årbog 1975, 81-92.

Nordmann, V. 1905: Danmarks Pattedyr i Fortiden. Danmarks geol. Unders., rakke 3, 5. København.

Nordmann, V. 1944: Jordfundne Pattedyrlevninger i Danmark. Dansk Natur. København.

Selsing, L. 1982: Radiocarbon dating of a mammoth tusk fragment from Brorfelde, Denmark. Bull. Geol. Soc. Denmark 31, 151-157.

Steenstrup, J. 1882: Om de geologiske Forhold i den nordlige Del af Vendsyssel. Indbydelsesskrift til Universitetets Aarsfest til Erindring om Kirkens Reformation. København.

Note added in press:

After the above survey had been handed in for printing, a "new" find of walrus was received in 1985 by Hjørring Museum (excavated c. 1975). The find comes from a - not geologically dated gravel-pit at Kirkholt near Hjørring in Northern Jutland.

This find consists of part of a canine which after $\mathrm{C}-14$ dating ( $\mathrm{K} 4473$ ) revealed an age of $23550 \pm 460$ before 1950 , or 21600 B.C. in C- 14 years.

Thus, this - youngest- find is in consonance with the two finds previously mentioned. 